\title{
Taxonomy and biogeography of tardigrades using an integrated approach: new results on species of the Macrobiotus hufelandi group
}

\author{
R. Bertolani ${ }^{1}$, V. Biserov ${ }^{\dagger 2}$, L. Rebecchi ${ }^{1}$, M. Cesari ${ }^{1}$ \\ ${ }^{1}$ Department of Biology, University of Modena and Reggio Emilia, Via Campi 213/D, 41125 \\ Modena, Italy. \\ e-mail:roberto.bertolani@unimore.it \\ ${ }^{2}$ Institute of Inland Water Biology, Academy of Sciences of Russia, Borok, Yaroslavl District, Russia
}

\begin{abstract}
This study considers in a new light a population already studied and tentatively attributed to Macrobiotus cf. terminalis (Bertolani, Rebecchi, 1993), by joining molecular approaches to the traditional, but indispensable, light microscopy, and to scanning electron microscopy. Differences in animal and, above all, egg shell morphology, and the peculiar coxl sequence indicate that this population clearly pertains to a new species, M. vladimiri sp.n., which is here described. The results obtained can be considered as an example of how a modern taxonomical and biogeographical research can be carried out on this animal phylum and in general on the animals belonging to the so called meiofauna, where characters bound to morphology are often very few. This is the first tardigrade species to be described and barcoded contemporarily.
\end{abstract}

KEY WORDS: tardigrades, Macrobiotus, DNA barcoding, coxl, biogeography, taxonomy.

\section{Использование комплексного подхода к таксономии и биогеографии тихоходок: новые данные по видам группы Macrobiotus hufelandi}

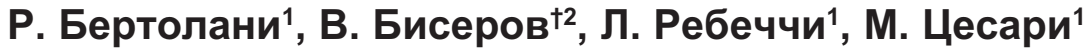 \\ ${ }^{1}$ Отдел биологии, Университет Модена и Реджио Эмилия, Виа Кампи, 213/D, 41125 Модена, \\ Италия. \\ e-mail: roberto.bertolani@unimore.it \\ ${ }^{2}$ Институт внутренних вод РАН, Борок, Ярославль, Россия
}

РЕЗЮМЕ: В настоящей работе в новом свете рассматривается уже изученная популяция, предварительно отнесенная к Macrobiotus cf. terminalis Бертолани и Ребекки (Bertolani, Rebecchi, 1993), с добавлением молекулярно-биологического подхода к традиционной, но необходимой световой микроскопии и сканирующей электронной микроскопии. Различия в морфологии животных и, кроме того, оболочки яиц, а также специфическая последовательность сох1 указывают, что эта популяция явно принадлежит к новому виду, M. vladimiri sp.n., описанному в данной работе. Полученные результаты можно рассматривать как пример того, как можно вести на современном уровне таксономические и биогеографические исследования животных, принадлежащих к этому типу, и в целом, к мейофауне, для которых набор 
морфологических признаков часто весьма ограничен. Это первый вид тихоходок, описанный в соответствии с современными стандартами классическими методами и с использование молекулярного анализа расшифровки ДНК.

КЛЮЧЕВЫЕ СЛОВА: тихоходки, Macrobiotus, ДНК, DNA barcoding, coxl, биогеография, таксономия.

\section{Introduction}

Even though the first description of a tardigrade species using the Linnaean nomenclature has been done only in the first half of the $19^{\text {th }}$ century by Carl August Sigismund Schultze (Schultze, 1834), very early, i.e. at the beginning of the $20^{\text {th }}$ century, the worldwide distribution (including the polar regions) of this animal group and its presence with several species in quite different environments (marine, freshwater and terrestrial) was already ascertained (Richters, 1903-1904, 1907, 1908, 1909, 1911; Murray, 1907a, 1907b, 1907c, 1913). At that time, the systematics of the group (considered as an order by Richters, Krumbach, 1926) was very simple, with very partial correspondence to what accepted today by the tardigradologists (Guidetti, Bertolani, 2005; Pilato, Binda, 2010). The systematics began to be deeply revised by Thulin (1928), who first used a phylogenetic approach to erect several genera and families. Marcus $(1929,1936)$ reconsidered the proposals by Thulin by reducing most genera at subgenus level, or not considering them valid. Cuènot (1932) also limited the number of genera and species (in the latter case proposing synonymies) and reduced the number of families to three for the entire class tardigrades, subdivided in two orders: Echinisci and Macrobioti. An approach not bound to phylogeny, even though with some new proposals (first of all Tardigrada as a phylum) was maintained by Ramazzotti (1962). In that monograph the author avoided to group the species according to genera, families and orders, but he listed them exclusively in alphabetic order of the specific name. In order to distinguish taxa, the morphology of some cuticular structures (external cuticle, claws, buccal tube, placoids, egg shell ornamentations) were used as useful characters, often retaining those structures as having a wide intra-specific variability (Ramazzotti, 1962). Different geographic regions were considered, but most work was devoted to Europe and the biogeographic aspect was absolutely not evaluated. At the end of the sixties Pilato (1969) re-considered the characters bound to the sclerified structures of the animals (claws, cuticular parts of the buccalpharyngeal apparatus), proposing a new taxonomical system for the class Eutardigrada based on the phylogeny. In the following years, he also evaluated new characters for the eutardigrade taxonomy, which were before completely or almost completely neglected, such as the buccal armature, the apophyses for the insertion of the stylet muscles on the buccal tube, the detailed shape of buccal and pharyngeal tube (Pilato, 1972, 1975). Comparing several specimens of a population and different populations of the same species, the author also evaluated the intraspecific variability, concluding that it is very low, the opposite to what was the common though. Some years later, he also proposed a system ( $p t$ value, e.g. the percent of the length, or width, of an un-deformable and well oriented structure with respect to the buccal tube length, excluding the mouth that can move) for the evaluation of quantitative characters (Pilato, 1981). In the seventies new methodological approaches devoted to the study of the tardigrade taxonomy have been proposed. Greven $(1971,1975)$ applied the transmission electron microscopy (TEM) to the study of the cuticle; some American authors introduced the use of the scanning electron microscopy (SEM) in the study of the details of the cuticle and the egg shell ornamentations (Schuster et al., 1975, 1980; Toftner et al., 1975). Some years later this methodological approach has been utilized in a 
comparative study of the spermatozoon morphology (Rebecchi, Guidi, 1991, 1993; Guidi, Rebecchi, 1996). The study of the morphology using SEM has been again utilized by Biserov on animals (Biserov, 1986). The most significant examples of egg morphology studies by SEM are some papers on the Macrobiotus of the so called "hufelandi group" (Biserov, 1990a, 1990b; Bertolani, Rebecchi, 1993). The first cladistic approach on tardigrades, based on morphology, has been carried out considering the heterotardigrade family Echiniscidae by Kristensen (1987). As regards biogeography, after the first considerations by Binda, Pilato (1973), the possibility to consider tardigrades from this point of view has been sustained by McInnes (1994) and again by Pilato, Binda (2001).

Molecular analyses on tardigrade phylogeny were at first directed towards its position with respect to other phyla (Garey et al., 1996, Giribet et al., 1996; Moon, Kim, 1996; Ryu et al., 2007; Dunn et al., 2008), while, at the turn of the millennium, the spotlight was shifted on relationships inside the phylum (Garey et al., 1999; Jørgensen, Kristensen, 2004; Regier et al., 2004; Guidetti et al., 2005, 2009; Nichols et al., 2006; Kiehl et al., 2007; Møbjerg et al., 2007; Sands et al., 2008a,b; Jørgensen et al., 2010). Even more recently, molecular investigations have begun to delve in intraspecific and intrapopulation variability, leading also to the discovery of cryptic species (Faurby et al., 2008; Guil, Giribet, 2009), and, after a few attempts on DNA taxonomy (Blaxter et al., 2004, 2005), to the demonstration that DNA barcoding can be applied to tardigrades (Cesari et al., 2009).

Considering the improving of the taxonomic approaches and having the opportunity to reexamine with these approaches the same population already studied and tentatively attributed to Macrobiotus cf. terminalis by Bertolani, Rebecchi (1993), we decided to reconsider it. This population differed from Macrobiotus terminalis Bertolani \& Rebecchi, 1993 for details of the egg shell and, above all for the absence of males in the population and its triploidy and ameiotic maturation of the oocytes (Bertolani,
Rebecchi, 1993). For years it was our common opinion that it should belong to a new species. Having found new material, we decided to carry out a further study in a new light, joining molecular methods (other than scanning electron microscopy) to the traditional, but indispensable, light microscopy, with the aim of resuming in the description and discussion of the animal and egg characteristics the most advanced available approach to carry out a modern tardigrade taxonomy and biogeography.

\section{Material and methods}

Animals and eggs described as Macrobiotus cf. terminalis and mounted in polyvinyl lactophenol, together with further animals and eggs collected on the same rock where $M$. cf. terminalis was found (Fig. 1), were analysed and compared with specimens of German populations collected in St. Ulrich (Freiburg). Some animals and eggs from the new collections of both populations have been mounted in FaureBerlese fluid for observations by light microscopy (LM). Some other eggs from the Italian population were prepared for scanning electron microscopy (SEM) following the protocol of Guidetti et al. (2000) and observed with a Philips SEM XL 40, available at the 'Centro Interdipartimentale Grandi Strumenti' at the University of Modena and Reggio Emilia (Italy). Considering the minimal size of tardigrades, the entire animal has to be used for DNA extraction; therefore, the animals processed for molecular analysis cannot be used as voucher specimens and vice versa. It is not the same for eggs: in several cases they can be isolated and maintained in caps with water until hatching. Single newborns obtained from these eggs can be used for DNA extraction, while their respective egg shells are mounted with Faure-Berlese fluid (Cesari et al., 2009), enabling to obtain hologenophore voucher specimens (Pleijel et al., 2008). Therefore, we have been able to correlate egg morphology and molecular data. For possible further investigation, a fragment of each collected samples was stored at $-80^{\circ} \mathrm{C}$ and several animals and eggs of each population 


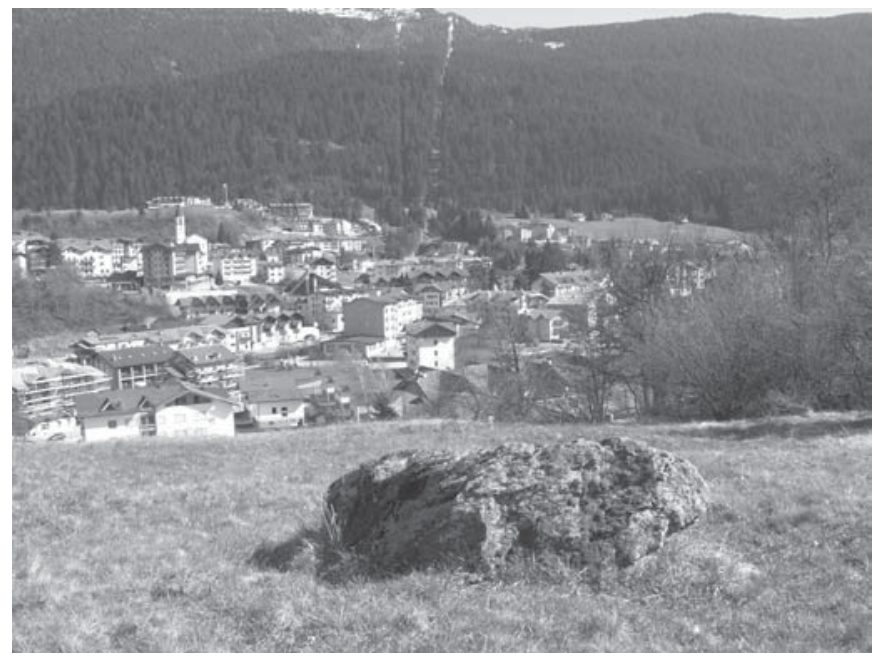

Fig. 1. The rock with moss patches in the type locality of Macrobiotus vladimiri sp.n., at Andalo, Italy. Рис. 1. Скала с пятнами мхов в типовом местообитании Macrobiotus vladimiri sp.n. Андало, Италия.

were preserved (paragenophores) both frozen and in Carnoy fluid (methanol:acetic acid 3:1) at the Department of Biology, Modena, Italy. All voucher specimens have been compared with type material in the tardigrade collection at the "Museo Civico di Storia Naturale" of Verona (Italy) and with the material in the collection of R. Bertolani, at the Department of Biology of the University of Modena and Reggio Emilia.

DNA was extracted from single specimens of adult animals (A) and from newborns from isolated eggs $(\mathrm{N})$ (Table 1), by using a rapid salt and ethanol precipitation as described by Cesari et al. (2009). PCR amplification of a fragment of the coxl gene was carried out in $20 \mu \mathrm{l}$ of reaction volume, which consisted of $2 \mu \mathrm{l}$ reaction buffer (including $20 \mathrm{mM}$ of $\mathrm{MgCl}_{2}$ ), 2.5 $\mathrm{mM}$ of each dNTP, $10 \mathrm{pM}$ (final concentration) of each primer (LCO-1490: 5'-GGT CAA CAA ATC ATA AAG ATA TTG G-3? and HCO2198: 5'-TAA ACT TCA GGG TGA CCA AAA AAT CA-3'; Folmer et al. 1994), 1 U of Dream Taq polymerase (Fermentas) and $2 \mu \mathrm{l}$ of template DNA. A negative control lacking template DNA was carried out to test the possibility of contamination with foreign DNA. PCR reaction was performed in a T-personal Thermal Cycler (Biometra), performing a step-up procedure, with the following protocol: the initial 5 cycles were performed with $1 \mathrm{~min}$ at $94^{\circ} \mathrm{C}, 1.5$ min at $42^{\circ} \mathrm{C}$ and $1.5 \mathrm{~min}$ at $72^{\circ} \mathrm{C}$, and they were followed by 35 cycles with $1 \mathrm{~min}$ at $94^{\circ} \mathrm{C}, 1.5$ $\min$ at $50^{\circ} \mathrm{C}$ and $1 \mathrm{~min}$ at $72^{\circ} \mathrm{C}$. The amplified products were gel purified using the Wizard Gel and PCR cleaning (Promega) kit. Both strands were sequenced using a ABI Prism 3100 sequencer (Applied Biosystems). Nucleotide sequences were aligned with the Clustal algorithm implemented in MEGA version 4 (Tamura et al. 2007; pairwise and multiple alignment parameters: Gap opening penalty: 15 , Gap extend penalty: 6.66) and checked by visual inspection. The sequences were translated to aminoacids by using the invertebrate mitochondrial code implemented in MEGA in order check for the presence of stop codons and therefore of pseudogenes. The nucleotide sequences of the newly analyzed specimens have been submitted to GenBank (NCBI's barcode designation HM136931-HM136934; Table 1). For appropriate molecular comparisons, we included in our analysis sequences pertaining to species of Macrobiotus hufelandi group: Macrobiotus macrocalix Bertolani \& Rebecchi, 1993: GenBank A.N. FJ176203-17 and AY598773-4; Macrobiotus terminalis Bertolani \& Rebecchi, 1993, AY598775 M. hufelandi group: FJ435804-6. A cox1 sequence of the eutardigrade Paramacrobiotus richtersi (Murray, 1911), AY598778-9 was used as the outgroup. A sequence pertaining to $M$. persimilis (EU244608) was included in the distance com- 
Table 1. Specimens' acronyms, source of DNA extraction and sampling information. Таблица 1. Обозначения изученных экземпляров, источник ДНК и сведения о пробах.

\begin{tabular}{|c|c|c|c|c|c|}
\hline Specimen & Source & Locality & Coordinates & Substrate & $\begin{array}{c}\text { GenBank } \\
\text { A.N. }\end{array}$ \\
\hline C2688-A01 & Adult & Andalo (Italy) & $\begin{array}{l}46^{\circ} \mathrm{N} 10.133 \\
11^{\circ} \mathrm{E} 00.017\end{array}$ & Moss on rock & HM136931 \\
\cline { 1 - 3 } C2688-A02 & Adult & Andalo (Italy) & HM136932 \\
\hline C2945-A01 & Adult & St. Ulrich (Germany) & $\begin{array}{l}47^{\circ} \mathrm{N} 54.532 \\
07^{\circ} \mathrm{E} 50.074\end{array}$ & Moss on wall & HM136933 \\
\cline { 1 - 3 } C2946-N01 & Newborn & St. Ulrich (Germany) & $\begin{array}{l}47^{\circ} \mathrm{N} 54.461 \\
07^{\circ} \mathrm{E} 49.999\end{array}$ & Moss on rock & HM136934 \\
\hline
\end{tabular}

putations, but was excluded from any phylogenetic analyses due to the fact that the sequence is not coding for a proper aminoacidic sequence. P-distance and Kimura 2 parameters (K2P) distance between scored haplotypes were determined using MEGA 4. Maximum Parsimony (MP) dendrogram was computed using PAUP* $4.01 \mathrm{~b} 10$ (Swofford, 2002) using a heuristic search; bootstrap values were obtained after 2000 replicates. Bayesian inference (BI) tree was calculated using MrBayes 3.1 (Ronquist, Huelsenbaeck, 2003), using the GTR + I model as detected by MrModeltest 2.3 (Nylander, 2004). The analysis was performed using 1000000 mcmc generations, with a burn-in of 2500 generations.

\section{Results}

\section{Morphological results}

The analysis of the mounted animals suggests the presence of at least two species of the "hufelandi group" with the typical shape of the pharyngeal bulb, containing two rod-shaped macroplacoids and an evident microplacoid, and a cuticle with "pearls" (pores). One species is certainly $M$. macrocalix, recognizable from the large buccal tube and the very evident anterior and posterior bands of teeth in the buccal armature. Other specimens certainly belong to M.cf. terminalis, being characterized by a buccal armature with not recognizable anterior band of teeth and with a posterior band well recognizable (but much less evident as in the previous species), indented lunules in the fourth pair of legs, other than a large size (as the previous species). Fig. 2A shows the shape of buccalpharyngeal apparatus, cuticle and claws of the first pair of legs of a specimen of this species; Fig. 2B the claws in the fourth pair of legs. Smaller animals with weak buccal armature and not recognizable teeth on the lunules could be juveniles of this species, or could belong to a third species.

The analyses by LM and SEM of the eggs of the "hufelandi group", surrounded by egg shell processes like inverted goblets or chalices, reveal the certain presence of three species, distinguishable by their different egg shell ornamentations. One type corresponds to the known and well recognizable shape of the egg of M. macrocalix, characterized by high processes, with large and smooth-edged distal disc, with a crown of large pits surrounding the process bases and very scarce (or null) and small pits in the other parts of the egg shell. A second type of egg shell (Fig. 2C, 2D) certainly is to be attributed to $M$. cf. terminalis. They are characterized by high processes but clearly smaller with respect to those of $M$. macrocalix, a distal disc with irregular edges, and an irregularly reticulated egg shell, having larger meshes around the bases of the processes and a thick meshwork. An identical egg shell has been found also in the German population from St. Ulrich (Fig. 2E). The third type of egg belongs to Macrobiotus sandrae Bertolani \& Rebecchi, 1993. It is easily recognizable by the smaller size of the processes, with a large distal disc with a little irregular edge, and by a very uniform reticulation of all the egg shell, represented by a very thin meshwork (Fig. 2F). 


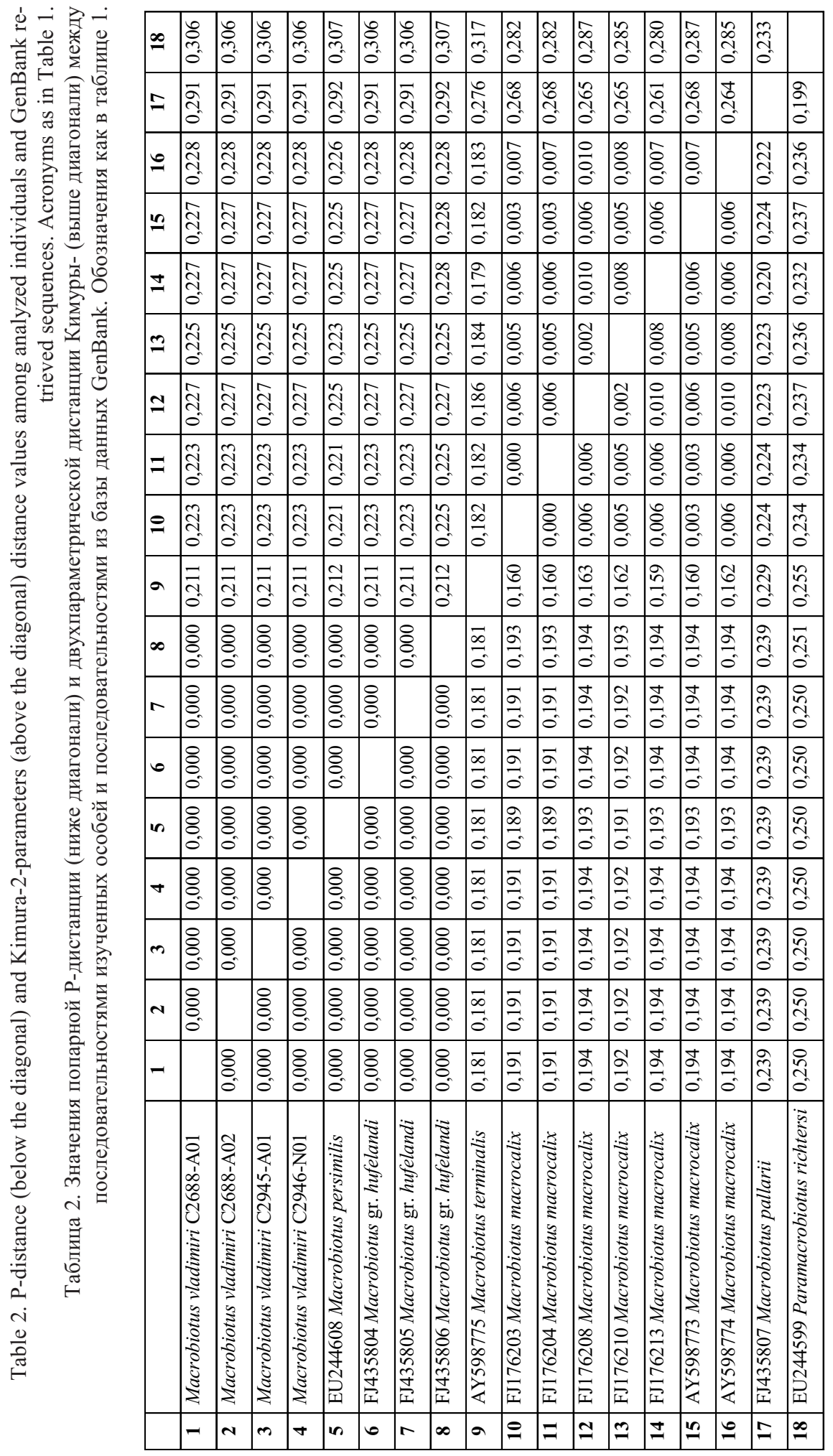



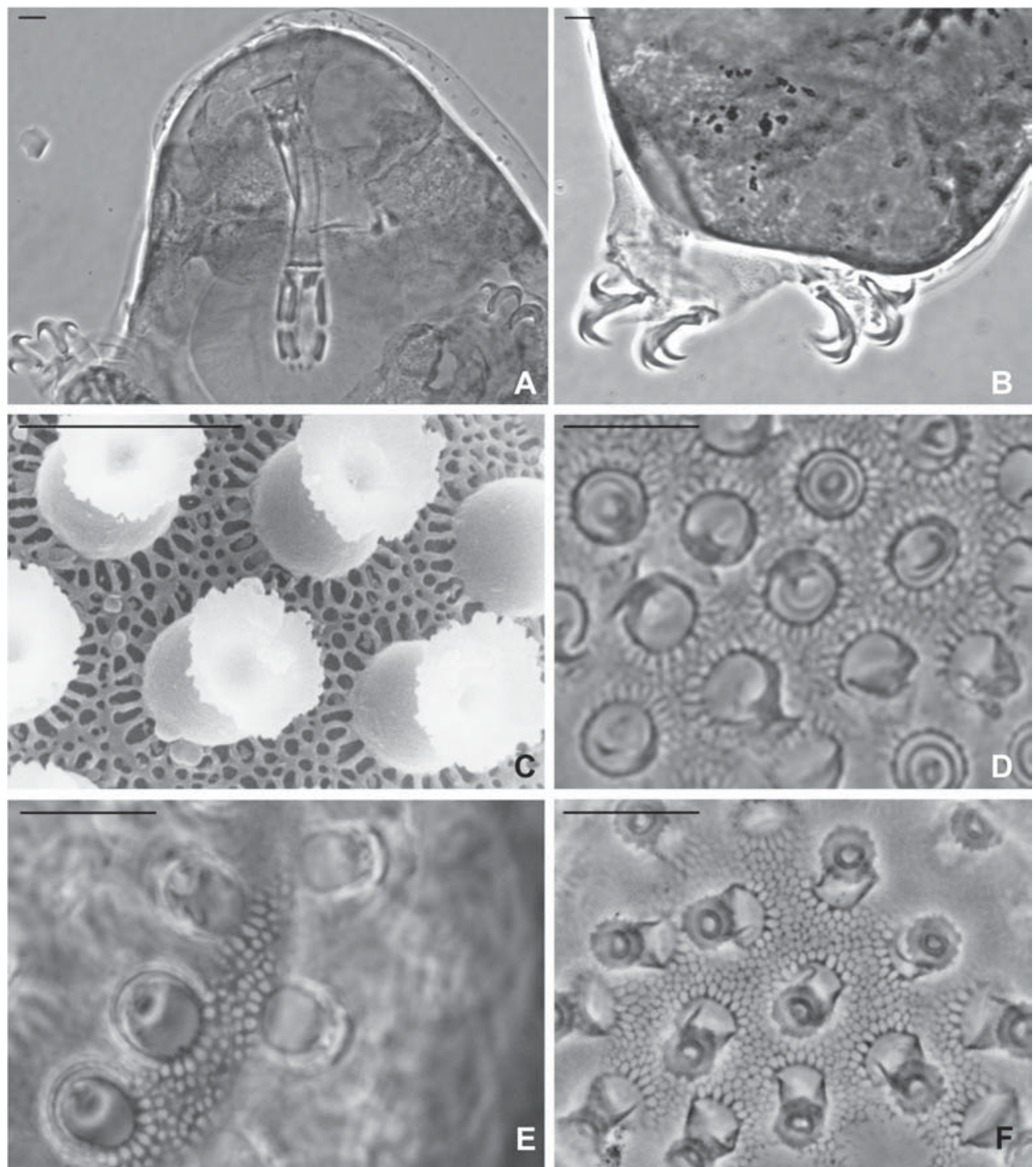

Fig. 2. Images of details of the holotype (A-B) and eggs (C-E) of Macrobiotus vladimiri sp.n. and of $M$. sandrae egg $(\mathrm{F})$.

A - buccal-pharyngeal apparatus, cuticular pores and claws in the first pair of legs (phase contrast); B — claws in the fourth pair of legs (phase contrast); C - detail of the ornamentation in an egg from Andalo (SEM); D - detail of the ornamentation in an egg from Andalo (phase contrast); E - detail of the egg ornamentation in a hologenophore of $M$. vladimiri sp. n. from St. Ulrich, Germany (phase contrast); F — detail of the ornamentation of an egg of $M$. sandrae from Andalo (phase contrast). Scale bar $5 \mu \mathrm{m}$.

Рис. 2. Детали морфологии голотипа (А-В) и яиц (С-E) Macrobiotus vladimiri sp.n., и яйца M. sandrae (F).

A - буккальный аппарат, кутикулярные поры и коготки первой пары ног (фазовый контраст); В — коготки четвертой пары ног (фазовый контраст); С - структура оболочки яйца из Андало (СЭМ); D - структура оболочки яйца из Андало (фазовый контраст); Е — структура оболочки яйца гологенофора M. vladimiri sp. n. из Санкт-Ульрих, Германия (фазовый контраст); F — структура оболочки яйца M. sandrae из Андало (фазовый контраст). Масштаб 5 мкм. 
Also in accordance with the molecular data (see below and Fig. 3), M. cf. terminalis should be considered a new species that will be here described, naming it Macrobiotus vladimiri sp.n., in honour of our colleague and co-author of this paper, with whom we begun to discuss together on the erection of this species before he passed away.

\section{Molecular results}

Molecular analysis was carried out on 624 bp of the 5' section of the mitochondrial coxl gene. The same haplotype was found in all analysed specimens, regardless of their sampling site (Table 2). Our scored haplotype was also the same as three GenBank sequences pertaining to the M. hufelandi group (Spain?) and also to a coxl-like sequence attributed to a German population of M. persimilis. All other comparisons with $M$. hufelandi group haplotypes showed very high distance values, ranging from $18.1 \%$ (vs M. terminalis) to $19.4 \%$ (vs $M$. macrocalix) (Table 2). MP and BI analyses have produced very similar tree topology (Fig. 3 ), evidencing that all haplotypes pertaining to the $M$. hufelandi group are clustered together with high bootstrap/posterior probability values. Inside this group, the specimens from Andalo and Germany utilized for the molecular analysis are more related to the $M$. terminalis from GenBank with respect to the M. macrocalix present in the same moss sample, even though the extent of genetic distance clearly distinguishes M. vladimi$r i$ sp.n. from all other species.

\section{Taxonomic account}

Macrobiotus vladimiri Bertolani, Biserov, Rebecchi et Cesari, sp.n.

Figs 2A-E, 4.

TYPE MATERIAL. Holotype: Adult (slide number C475-S18) collected in Andalo (Trento, Italy), deposited in Bertolani's collection in the Department of Biology, University of Modena and Reggio Emilia, Modena, (Italy).

40 paratypes and 14 eggs from Andalo, deposited in Bertolani's collection.

TYPE LOCALITY. Andalo, Italy, moss sample on rock, $46^{\circ} \mathrm{N} 10.133 ; 11^{\circ} \mathrm{E} 00.017,1050 \mathrm{~m}$ above sea level (Fig. 1).
ETYMOLOGY. The species is dedicated to our colleague and friend Vladimir I. Biserov, who passed away too early.

DIAGNOSIS. A large Macrobiotus of the "hufelandi group", with eyes, smooth cuticle with "pearls", buccal armature with a posterior band of teeth followed by transverse crests always three and separated both dorsally and ventrally, two rod-shaped macroplacoids and miroplacoid, lunules smooth on the first three pairs of legs, larger and weakly indented on the fourth pair of legs. Eggs laid freely, with inverted goblet processes on a reticulated shell. Margin of the distal disc of the processes jagged. Meshwork thick, surrounding pits larger around the processes. Triploid and thelytokous, with an ameiotic oocyte maturation.

HOLOTYPE DESCRIPTION. The holotype and its details are represented in Fig. 4. Animal length $491 \mu \mathrm{m}$. Eye spots present. Smooth cuticle, with seed-shaped pores and with transversal bands of pigment (these bands are not a constant presence in the other specimens of the same population). Granulations on the legs, but not much developed. Buccal armature: peribuccal lamellae consistent, anterior band of teeth not visible, posterior band of fine teeth, followed caudally by three dorsal and three ventral always separated transverse crests. These crests are dorsally longer than the ventral ones; the median ventral crest is small and roundish. Buccal tube $49.5 \mu \mathrm{m}$ in length, with an internal diameter (measured at the level of the insertion of the stylet supports) of $5.7 \mu \mathrm{m}$ (external $6.5 \mu \mathrm{m}$ ). Ventral strengthening bar $22.8 \mu \mathrm{m}$ in length. Bulb roundish, with large apophyses, two rod-shaped macroplacoids (the first practically without narrowing, the second without constriction) and microplacoid. Placoid row, including microplacoid, $24.0 \mu \mathrm{m}$ in length, macroplacoid row $21.5 \mu \mathrm{m}$, first macroplacoid $12.2 \mu \mathrm{m}$, second macroplacoid $7.9 \mu \mathrm{m}$. Microplacoid thin and only $1.8 \mu \mathrm{m}$ in length. Strong claws, with evident accessory points on their main branches and with small and smooth lunules in I-III pairs of legs, larger and slightly indented in the fourth pair. External claw in the II pair: $11.7 \mu \mathrm{m}$ excluding the accessory points 
(12.1 with accessory points); posterior claw in the IV pair: $12.4 \mu \mathrm{m}$ (13.4 $\mu \mathrm{m}$ with accessory points). All measurements have been taken according to Pilato (1981).

The paratypes (from 322.6 to $515.1 \mu \mathrm{m}$ in length) correspond in the qualitative characters to the holotype, apart the absence of pigment in several of them, and the difficulty in some specimens in identifying the teeth on the lunules of the fourth pair of legs.

Eggs laid freely (89.9-92.0 $\mu \mathrm{m}$ in diameter, without processes), with processes as inverted goblet, with distal disc a little narrower than the base and with clearly jagged margin. Reticulated egg shell, with thick meshwork, including oval or round pits, larger and wider in the peribasal ring around the processes.

From 82 to 92 processes per hemisphere. Height of processes: $6.5-8.0 \mu \mathrm{m}$; diameter of process bases: 5.1-7.3 $\mu \mathrm{m}$; diameter of distal dish: 3.8$4.8 \mu \mathrm{m}$; diameter mesh at the base of the processes: $0.5 \mu \mathrm{m}$.

REMARKS. The new species can be distinguished from other species of the Macrobiotus hufelandi group for some details of the animals but mainly for the shape of its eggs. In particular, it can be distinguished from several species of the group that have a unique dorsal transverse crest in the buccal armature. Considering some species with three separated dorsal transverse crests, $M$. vladimiri can be distinguished from M. persimilis (that has similar slightly indented lunules in the fourth pair of legs) for the lack of a very deep narrowing in the first macroplacoid, but also for a quite different type of egg (with deeply indented distal disc and without reticulation in $M$. persimilis). It can also be distinguished from $M$. terminalis for the absence of males and for the egg processes higher (4.6-6.0 $\mu \mathrm{m}$ in $M$. terminalis) and with the distal disc more irregular. It differs from $M$. sandrae for the larger size, for the presence of indented lunules (when visible), for a longer placoid row and for bigger eggs, with higher processes and different reticulation.

Macrobiotus vladimiri sp.n. is the first tardigrade species to be described and barcoded contemporarily.

\section{Discussion}

Molecular analysis using cox $1 \mathrm{mtDNA}$ clearly demonstrates that what was tentatively attributed to $M$. cf. terminalis it is certainly to be considered a different species, here erected with the name $M$. vladimiri sp.n. This situation could be suspected also from the different sex condition which distinguishes the $M$. terminalis population collected in the type locality (central Italy), which has males (and therefore very probably diploid), from that collected at Andalo (northern Italy), where males are lacking and the oocytes were triploid and ameiotic (Bertolani, Rebecchi, 1993). At that time, due to the similarity of animals and eggs, it could be suspected that theoretically there could be some gene flow between the two populations, but our unpublished data on Paramacrobiotus richtersi group, based on cox 1 sequence analysis (Guidetti et al., in preparation) clearly reveal that triploid and diploid populations always have a very large genetic distance. It is important to note that between $M$. terminalis and $M$. vladimiri sp.n. there are also differences in the egg shell shape (see Remarks). Moreover, the M. terminalis sequence present in GenBank, even though it is not sampled in the type locality, shows very high diversity values with respect to $M$. vladimiri sp.n., well above the $3 \%$ threshold proposed for identifying different species (Hebert et al., 2003a, 2003b; Cesari et al., 2009). In the case of M. vladimiri sp.n. morphology alone, even though at fine level, can identify the species. Nonetheless, molecular analysis can help to evidence true cryptic species, not identifiable only on morphological basis, as results from the data by Faurby et al. (2008), by Guil, Giribet (2009) and from our unpublished data on $P$. richtersi group.

All together, molecular analysis, morphological analysis (in particular, but not only, that devoted to the fine morphology by LM and SEM of the egg shell), sex condition evaluation and karyology can be very helpful in species identification. In particular, it is important to underline the datum from St. Ulrich, deriving from a newborn individual, whose egg shell has 


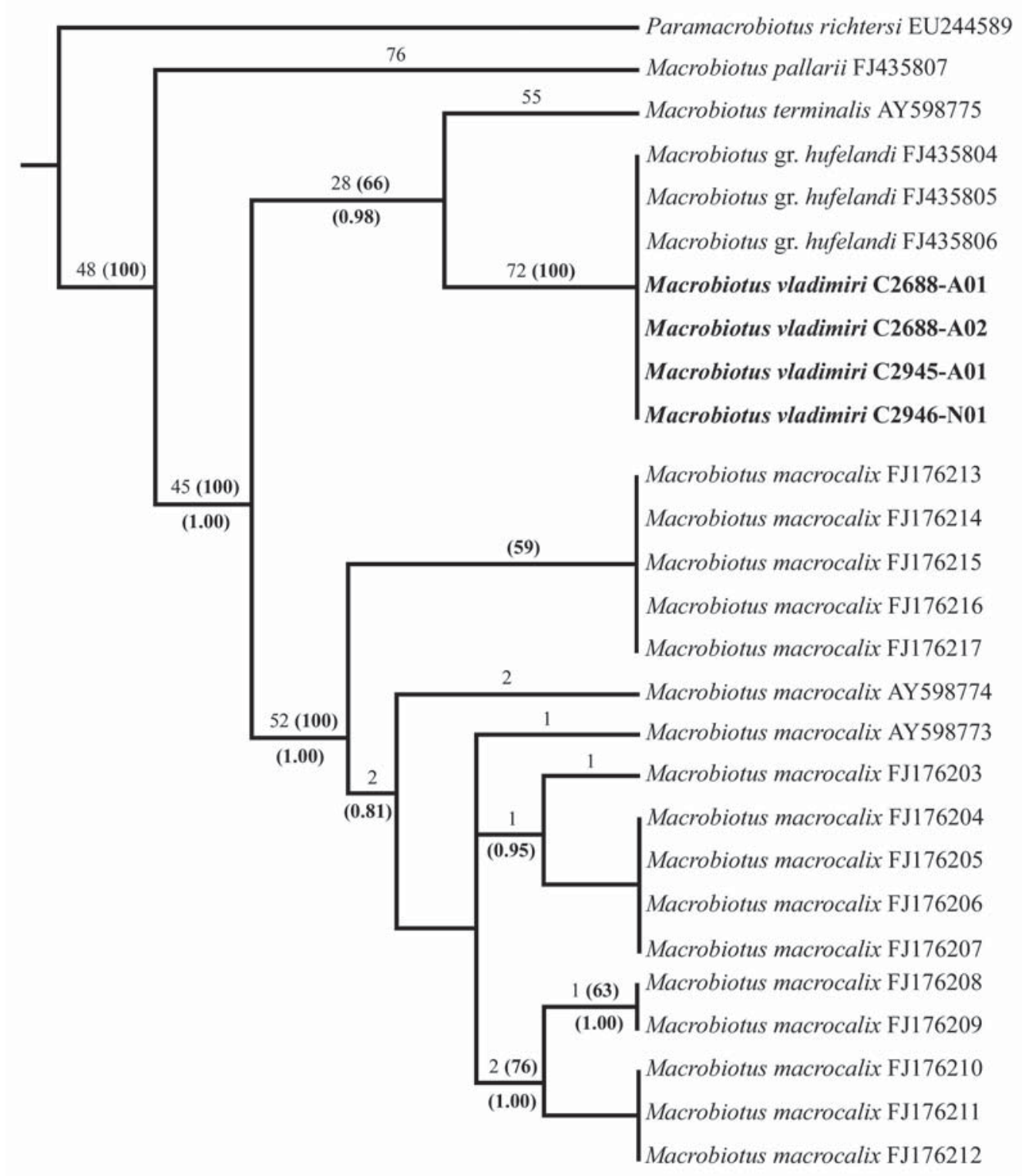

Fig. 3 Dendrogram combining Bayesian and maximum parsimony (consistency index: 0.824; retention index: 0.930; rescaled consistency index: 0.767 ) analyses. Numbers above branches indicate substitutions, while numbers in bold and in parentheses show bootstrap values (above branches) and posterior probability values (below branches). Acronyms as in Table 1.

Рис. 3. Дендрограма, объединяющая Байесовский анализ и анализ на основе метода максимальной экономии. Цифры над ветвями обозначают замены, а числа, показанные жирным шрифтом и в скобках, показывают бутстрап-значения (над ветвями) и значения апостериорной вероятности (под ветвями). Сокращения как в таблице 1 . 


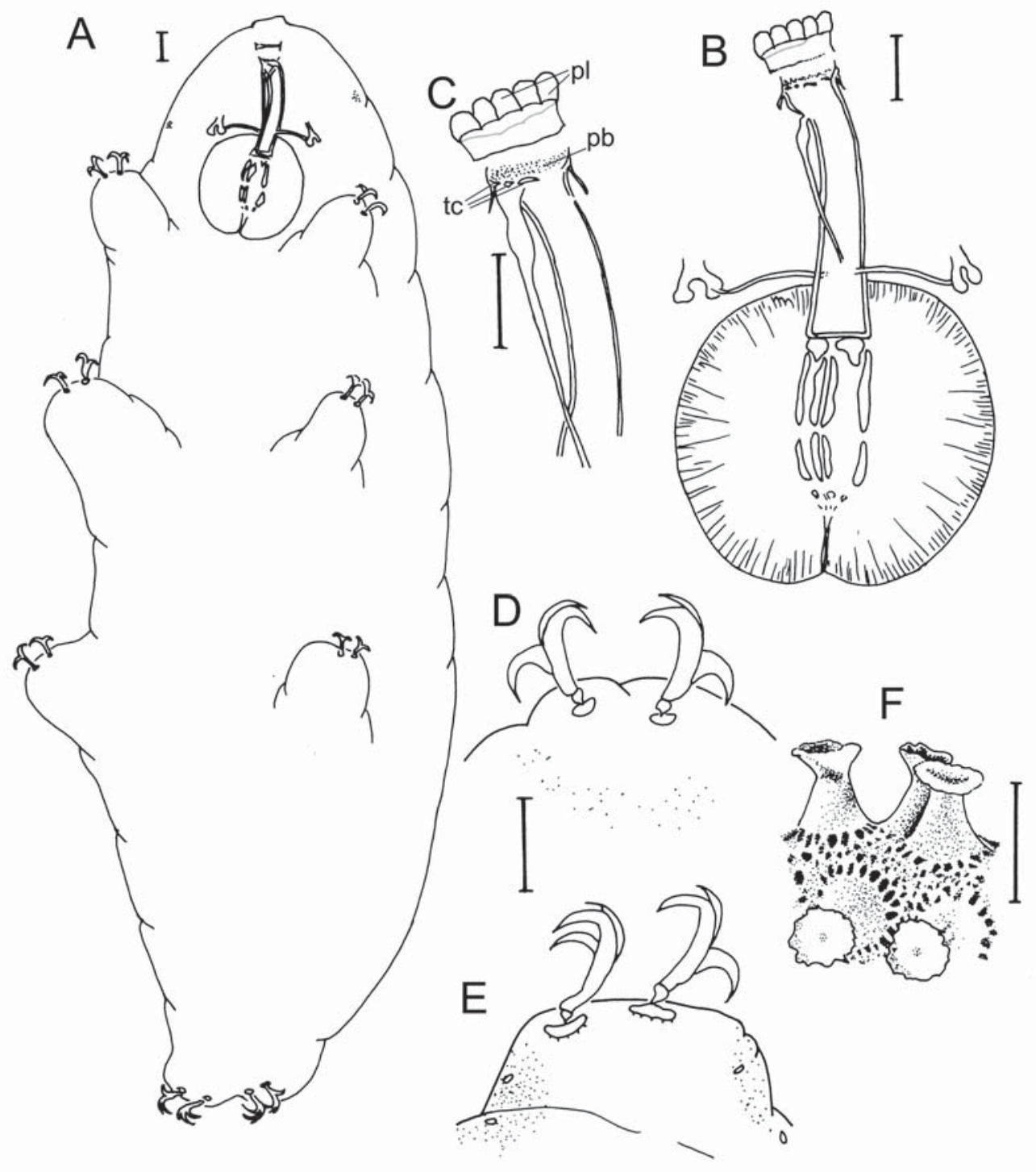

Fig. 4. Drawing of the holotype and of the detail of an egg from Andalo of Macrobiotus vladimiri sp.n. A - habitus; B - buccal-pharyngeal apparatus; C — detail of the ventral buccal armature; D — claws in the first pair of legs; E - claws in the fourth pair of legs; $\mathrm{F}$ - detail of the egg shell.

Abbreviations: $\mathrm{pb}$ - posterior band of teeth; $\mathrm{pl}$ - peribuccal lamellae; tc — transverse crests. Scale bar 5 $\mu \mathrm{m}$.

Рис. 4. Рисунок голотипа и детали строения яйца Macrobiotus vladimiri sp.n. из Андало.

A - общий вид; В - буккальный аппарат; C - детали вентрального вооружения глотки; D - коготки первой пары ног; Е — коготки четвертой пары ног; F — структура оболочки яйца.

Обозначения: $\mathrm{pb}$ - задний ряд зубов; $\mathrm{pl}$ - перибуккальные ламеллы; tc — поперечные гребни. Масштаб 5 мкм. 
been permanently mounted (hologenophore sen$s u$ Pleijel et al. 2008; Fig. 2E), which allows to relate DNA sequence and egg morphology. Moreover, molecular analysis using $\operatorname{cox} l$ is also useful to identify the relationships among species within a genus and to identify or confirm species groups, such as, for example, the "hufelandi group" within the genus Macrobiotus. In fact, all $M$. "hufelandi group" sequences cluster together in the MP and BI dendrograms (Fig. 3), supported by high bootstrap/posterior probability values. Inside this group, M. vladimiri and previously analyzed $M$. macrocalix haplotypes are very well differentiated from each other and from sequences pertaining to all other $M$. hufelandi group, pointing out their marked diversity inside the group. Further analyses on different species pertaining to this group should help clarify the different relationships inside the $M$. "hufelandi group". The molecular data related to coxl allows also to gain sure information on the geographic distribution of the species. For long time it was believed that most tardigrades could have a cosmopolitan, or very widespread, distribution (Ramazzotti, Maucci, 1983), but in reality this opinion was due to the fact that tardigrade sclerified structures were considered highly variable inside the species. However, papers of the last 30-40 years have demonstrated that many species have very limited morphological variability (Pilato, 1972) and a limited distribution (Pilato, Binda, 2001). Our molecular data on M. vladimiri, compared with the data from GenBank, also point out that this species has a wide distribution in Europe. In fact, genetic distances (Table 2 and Fig. 3) reveal that $M$. vladimiri sp.n. is present even in Germany, in our material collected at St. Ulrich, and in Spain (data from GenBank cited as Macrobiotus gr. hufelandi). Further data on this and other species can easily verify, avoiding mistakes and misunderstandings, the real distribution on the specific taxa.

In conclusion, methodological approaches applied to tardigrade taxonomy have been deeply improved in the last decades. The results obtained with the different approaches on the animals and their eggs here studied can be considered as an example of how a modern taxonomical and biogeographical research can be carried out on this animal phylum and more in general in taxonomy of many other animal phyla, especially those belonging to the so called meiofauna, where characters bound to morphology are often very few.

\section{Acknowledgments}

The authors wish to thank Natalia Biserova for the invitation to give our contribution to honor her husband Vladimir Biserov. We are grateful to Diane R. Nelson, East Tennessee State University for the English revision of the manuscript and her helpful suggestions. We thank the "Museo Civico di Storia Naturale di Verona", Verona, Italy, for the loaned material. The research is part of the project MoDNA supported by Fondazione Cassa di Risparmio di Modena and the University of Modena and Reggio Emilia. The drawings are by Michele Cesari and Donato Giannetti.

\section{References}

Bertolani R., Rebecchi L. 1993. A revision of the Macrobiotus hufelandi group (Tardigrada, Macrobiotidae), with some observations on the taxonomic characters of eutardigrades // Zoologica Scripta. Vol.22. P.127-152.

Binda M.G., Pilato G. 1973. Le attuali conoscenze sulla fauna tardigradologica di alcune piccole isole circumsiciliane // Lavori della Societá Italiana di Biogeografia. N.S. Vol.3. P.1-7 [in Italian].

Biserov V.I. 1986. [Terrestrial water bears from the North Caucasus. 1. Heterotardigrada] // Zoologichesky Zhurnal. Vol.65. P.474-756 [in Russian].

Biserov V.I. 1990a. [On the revision of the genus Macrobiotus. The subgenus Microbiotus s. str.: a new systematic status of the group hufelandi (Tardigrada, Macrobiotidae). Communication 1] // Zoologichesky Zhurnal. Vol.69. P.5-17 [in Russian].

Biserov V.I. 1990b. [On the revision of the Macrobiotus genus. The subgenus Macrobiotus s. str. is a new taxonomic status of the hufelandi group (Tardigrada, Macrobiotidae). Communication] // Zoologichesky Zhurnal. Vol.69. P.38-50 [in Russian].

Blaxter M., Elsworth B., Daub J. 2004. DNA taxonomy of a neglected animal phylum: an unexpected diversity of tardigrades // Proceedings of the Royal Society of London Series B. Vol.271. P.S198-S192.

Blaxter M., Mann J., Chapman T., Thomas F., Whitton C., Floyd R., Abebe E. 2005. Defining operational taxo- 
nomic units using DNA barcode data // Philosophical Transactions of the Royal Society Series B. Vol.360. P.1935-1943.

Cesari M., Bertolani R., Rebecchi L., Guidetti R. 2009. DNA barcoding in Tardigrada: the first case study on Macrobiotus macrocalix Bertolani \& Rebecchi 1993 (Eutardigrada, Macrobiotidae) // Molecular Ecology Resources. Vol.9. P.699-706.

Cuènot L. 1932. Tardigrades // Faune de France. Paris: Paul Lechevalier. Vol.24. P.1-96.

Dunn C.W., Hejnol, A., Matus D.Q. et al. 2008. Broad phylogenomic sampling improves resolution of the animal tree of life // Nature. Vol.452. P.745-750.

Faurby S., Jönsson K.I., Rebecchi L., Funch P. 2008. Variation in anhydrobiotic survival of two eutardigrade morphospecies: a story of cryptic species and their dispersal // Journal of Zoology, London. Vol.275. P.139-145.

Folmer O., Black M., Hoeh W., Lutz R., Vrijenhoek R. 1994. DNA primers for amplification of mitochondrial cytochrome c oxidase subunit I from diverse metazoan invertebrates // Molecular Marine Biology and Biotechnology. Vol.3. P.294-299.

Garey J.R., Krotec M., Nelson D.R., Brooks J. 1996. Molecular analysis supports a tardigrade-arthropods association // Invertebrate Biology. Vol.115. P.79-88.

Garey J.R., Nelson D.R., Mackey L.Y., Li J. 1999. Tardigrade phylogeny: congruency of morphological and molecular evidence //Zoologischer Anzeiger. Vol.238. P.205-210.

Giribet G., Carraza S., Baguna J., Rintort M., Ribera C. 1996. First Molecular Evidence for the Existence of a Tardigrada + Arthropoda Clade // Molecular Biology and Evolution. Vol.13. P.76-84.

Greven H. 1971. Zur Feinstruktur der inneren Epicuticula von Echiniscus testudo // Die Naturwissenschaften. Vol.7. P.367-368.

Greven H. 1975 New results and considerations regarding the fine structure of the cuticle in Tardigrades // Memorie dell'Istituto Italiano di Idrobiologia. Vol.32. Suppl. P.113-131.

Guidetti R., Bertolani R. 2005. Tardigrade taxonomy: an updated check list of the taxa and a list of characters used in their identification // Zootaxa. Vol.845. P.1-46.

Guidetti R., Gandolfi A., Rossi V., Bertolani R. 2005. Phylogenetic analysis in Macrobiotidae (Eutardigrada, Parachela): a combined morphological and molecular approach // Zoologica Scripta. Vol.34. P.235244.

Guidetti R., Rebecchi L., Bertolani R. 2000. Cuticle structure and systematics of the Macrobiotidae (Tardigrada, Eutardigrada) // Acta Zoologica. Vol.81. P.27-36.

Guidetti R., Schill R.O., Bertolani R., Dandekar T., Wolf M. 2009. New molecular data for tardigrade phylogeny, with the erection of Paramacrobiotus gen. n. // Journal of Zoological Systematics and Evolutionary Research Vol.47. P.315-321.

Guidi A., Rebecchi L. 1996. Spermatozoan morphology as a character for tardigrade systematics: comparison with sclerified parts of animals and eggs in eutardigrades // Zoological Journal of the Linneian Society Vol.116. P.101-113.

Guil N., Giribet G. 2009. Fine scale population structure in the Echiniscus blumi-canadensis series (Heterotardigrada, Tardigrada) in an Iberian mountain range When morphology fails to explain genetic structure // Molecular Phylogenetics and Evolution. Vol.1.P.606613.

Hebert P.D.N., Cywinska A., Ball S.L., deWaard J.R. 2003a. Biological identifications through DNA barcodes // Proceedings of the Royal Society B. Vol.270. P.596-599.

Hebert P.D.N., Ratnasingham S., deWaard J.R. 2003 b. Barcoding animal life: cytochrome c oxidase subunit 1 divergences among closely related species / / Proceedings of the Royal Society B. Vol.270. P.313-321.

Jørgensen A., Faurby S., Hansen J.H., Møbjerg N., Kristensen R.M. 2010. Molecular phylogeny of Arthrotardigrada (Tardigrada) // Molecular Phylogenetics and Evolution. Vol.54. P.1006-1015.

Jørgensen A., Kristensen R.M. 2004. Molecular phylogeny of Tardigrada-investigation of the monophyly of Heterotardigrada // Molecular Phylogenetics end Evolution. Vol.32. P.666-670.

Kieh1 E., Dastych H., D’Haese J., Greven H. 2007. The 18 S rDNA sequences support polyphyly of the Heterotardigrada // Journal of Limnology. Vol.66. P.21-25.

Kristensen R.M. 1987. Generic revision of the Echiniscidae (Heterotardigrada), with a discussion of the origin of the family // In: R. Bertolani (ed.) Biology of Tardigrades Sel. Symp. Monogr. U.Z.I. Modena. Mucchi Vol.1. P. 261-335.

Marcus E. 1929. Tardigrada // H.G. Bronns Klassen und Ordnungen des Tierreichs. Leipzig. Bd.5. S.1-608.

Marcus E. 1936. Tardigrada // Das Tierreich. Berlin und Leipzig: W. de Gruyter. Bd.66. S.1-340.

McInnes S.J. 1994. Zoogeographic distribution of terrestrial/freshwater tardigrades from current literature // Journal of Natural History. Vol.28. P.257-352.

Møbjerg N., Jørgensen A., Eibye-Jacobsen J., Halberg K.A., Persson D., Kristensen R.M. 2007. New records on cyclomorphosis in the marine eutardigrade Halobiotus crispae // Journal of Limnology. Vol.66. P.132140.

Moon S., Kim W. 1996. Phylogenetic position of the Tardigrada based on the $18 \mathrm{~S}$ ribosomal RNA gene sequences // Zoological Journal of the Linneian Society. Vol.116. P.61-69.

Murray J. 1907a. Some Tardigrada of the Sikkim Himalaya // Journal of the Royal Microscopic Society. Vol.3. P.269-273.

Murray J. 1907b. Arctic Tardigrada, collected by Wm. S. Bruce // Transasctions of the Royal Society of Edinburgh. Vol.45. Part 3. P.669-681.

Murray J. 1907c. Some South African Tardigrada // Journal of the Royal Microscopical Society. Vol.5. P.515-524.

Murray J. 1913. African Tardigrada // Journal of the Royal Microscopical Society. Part 2. P.136-144. 
Nichols P.B., Nelson D.R., Garey J.R. 2006. A family level analysis of tardigrade phylogeny // Hydrobiologia. Vol.558. P.53-60.

Nylander J.A.A. 2004. MrModeltest 2.3. Program distributed by the author. Evolutionary Biology Centre. Uppsala University.

Pilato G. 1969. Evoluzione e nuova sistemazione degli Eutardigrada // Bollettino di Zoologia, Vol.36. P327345 [in Italian].

Pilato G. 1972. Structure, Intraspecific Variability, and Systematic Value of the Buccal Armature of Eutardigrades // Zeitschrift für Zoologische Systematik und Evolutionsforschung. Vol.10. P.65-78.

Pilato G. 1975. On the taxonomic criteria of the Eutardigrada // Memorie dell'Istituto Italiano di Idrobiologia. Vol.32 Suppl. P.277-303.

Pilato G. 1981. Analisi di nuovi caratteri nello studio degli Eutardigradi // Animalia. Vol.8. P.51-57.

Pilato G., Binda M.G. 2001. Biogeography and limnoterrestrial tardigrades: are they truly incompatible binomials? // Zoologisher Anzeiger. Bd.240. P.511516.

Pilato G., Binda M.G. 2010. Definition of families, subfamilies, genera and subgenera of the Eutardigrada, and keys to their identification // Zootaxa. No.2404. P.1-54.

Pleijel F., Jondelius U., Norlinder E. et al. 2008. Phylogenies without roots? A plea for the use of vouchers in molecular phylogenetic studies // Molecular Phylogenetic and Evolution. Vol.48. P.369-371.

Ramazzotti G. 1962. Il Phylum Tardigrada // Memorie dell'Istituto Italiano di Idrobiologia. Vol.14. P.1-595.

Ramazzotti G., Maucci W. 1983. Il Phylum Tardigrada. III Edizione riveduta e aggiornata // Memorie dell'Istituto Italiano di Idrobiologia. Vol.41. P.1-1012.

Rebecchi L., Guidi A. 1991. First SEM studies on tardigrade spermatozoa // Invertebrate Reproduction and Development. Vol.19. P.151-156.

Rebecchi L., Guidi A. 1993. SEM and TEM observations on spermatozoa of eutardigrades from fresh-water and terrestrial environments // Proceedings of Multinational Congress on Electron Microscopy, Parma. Miscroscopia Elettronica. Vol.14. Suppl. P.467-468.

Rebecchi L., Guidi A. 1995. Spermatozoon Ultrastructure in Two Species of Amphibolus (Eutardigrada, Eohypsibiidae) // Acta Zoologica. Vol.76. P.171-176.

Regier J.C., Shultz J.W., Kambic R.E., Nelson D.R. 2004. Robust support for tardigrade clades and their ages from three protein-coding nuclear genes// Invertebrate Biology. Vol.123. P93-100.

Richters F. 1903-1904. 6. Nordische Tardigraden // Zoologisher Anzeiger. Bd.27. S.168-174.
Richters F 1907. 9. Antarktische Tardigraden // Zoologisher Anzeiger. Bd.31. S.915-917.

Richters F. 1908 12. Marine Tardigraden // Zoologisher Anzeiger. Bd.33. S.77-85.

Richters F. 1909. 9. Tardigraden unter $77^{\circ} \mathrm{S}$. Br // Zoologisher Anzeiger. Bd.34. S.604-607.

Richters F. 1911. Wissenschaftliche Mitteilungen. 1. Südamerikanische Tardigraden // Zoologisher Anzeiger. Bd.38. S.273-277.

Richters F., Krumbach T. 1926. Tardigrada // Kükenthal W., Krumbach T. (Hrsg.). Handbuch der Zoologie. III. Berlin und Leipzig. S.1-68.

Ronquist F., Huelsenbeck J.P. 2003. MRBAYES 3: Bayesian phylogenetic inference under mixed models // Bioinformatics. Vol.19. P.1572-1574.

Ryu S.H., Lee J.M., Jang K.H., Choi E.H., Park S.J., Chang C.Y., Kim W., Hwang U.W. 2007. Partial mitochondrial gene arrangements support a close relationship between Tardigrada and Arthropoda // Molecules and Cells. Vol.24. P.351-357.

Sands C.J., Convey P., Linse K., McInnes S.J. 2008a. Assessing meiofaunal variation among individuals utilizing morphological and molecular approaches: an example using the Tardigrada // BMC Ecology. Vol.8. P.7.

Sands C.J., McInnes S.J., Marley N.J., Goodall-Copestake W.P., Convey P., Linse K. 2008b. Phylum Tardigrada: an "individual" approach // Cladistics. Vol.24. P1-11.

Schultze C.A.S. 1834. Macrobiotus Hufelandii animal e crustaceorum classe novum, reviviscendi post diuturnam asphyxian et ariditaten potens, etc. // 8 Seiten, 1 tab. C. Curths, Berlin, 6 p., I Table.

Schuster R.O., Grigarick A.A., Toftner E.C. 1975. Ultrastructure of Tardigrade Cuticle// Memorie dell'Istituto Italiano di Idrobiologia. Vol.32 Suppl. P.337-375.

Schuster R.O., Nelson D.R., Grigarick A.A., Christenberry D. 1980. Systematic criteria of the Eutardigrada // Transactions of the American Microscopical Society. Vol.99. P.284-303.

Swofford D.L. 2002. PAUP* Phylogenetic Analysis Using Parsimony (* and other methods). Version $4.0 \mathrm{~b} 10$ win32 // Sinauer \&Associates, Sunderland, Massachusetts.

Tamura K., Dudley J., Nei M., Kumar S. 2007. MEGA4: Molecular Evolutionary Genetics Analysis (MEGA), software version 4.0 // Molecular Biology and Evolution. Vol.24. P.1596-1599.

Thulin G. 1928. Über die Phylogenie und das System der Tardigraden // Hereditas. Vol.11. P.207-266.

Toftner E.C., Grigarick A.A., Schuster R.O. 1975. Analyses of scanning electron microscope images of Macrobiotus eggs // Memorie dell'Istituto Italiano di Idrobiologia. Vol.32 Suppl. P.393-412. 